\title{
Influences of Different Coating Materials on the Quality Changes of Hardboiled Salted Duck Eggs under Ambient Storage
}

\section{Karthikeyan Venkatachalam ${ }^{1}$}

https://orcid.org/0000-0002-1028-0590

\section{Somwang Lekjing ${ }^{1}$}

https://orcid.org/0000-0001-7013-7625

\author{
Paramee Noonim ${ }^{*}$ \\ https://orcid.org/0000-0001-9451-3197
}

\begin{abstract}
1 University (Surat Thani Campus), Faculty of Science and Industrial Technology, Department of Food Technology, Prince of Songkla Muang, Surat Thani, Thailand.
\end{abstract}

Received: 2018.08.31; Accepted: 2019.07.08.

*Correspondence: paramee@psu.ac.th; Tel.: +66-77-278880 (P.M.)

\section{HIGHLIGHTS}

- Edible and non-edible coating materials influenced the salted duck eggs quality.

- WPI effectively controlled the oxidation in salted duck eggs compared to others.

- $\mathrm{CH}, \mathrm{WPI}$ and SPI protected the salted eggs from the yeast and mold growth.

- Sensory qualities in the salted duck eggs were significantly affected.

\begin{abstract}
The present study investigated the influences of selected coatings (paraffin wax $(\mathrm{PW})$, chitosan $(\mathrm{CH})$, whey protein isolate (WPI), and soy protein isolate (SPI)) on the quality changes of hardboiled salted duck eggs when kept under ambient temperature $\left(30 \pm 2{ }^{\circ} \mathrm{C}\right)$. At 5 -day intervals for 15 days, samples were tested for color $\left(L^{*}, C^{*}\right.$, and $\left.h^{\circ}\right)$, shell strength, weight loss, microbial analysis, water activity, moisture, $\mathrm{pH}$, salt content, TBARS, and sensory analysis. $L^{*}, C^{*}$ and $h^{\circ}$ gradually decreased in egg white, whereas $C^{*}$ and $h^{\circ}$ gradually increased in egg yolk. Shell strength gradually decreased in all cases, and weight loss similarly increased throughout the storage. PW and WPI coatings gave the best shell strengths and the least weight loss. The $a_{w}$ was not significantly different between the treatments. WPI and PW retained the most moisture. A slight decrease in $\mathrm{pH}$ was observed in all the samples $(P \geq 0.05)$. On the other hand, salt content gradually increased with storage time, and the WPI and SPI treatments gave $<2 \%$ salt accumulation. TBARS steadily increased throughout storage, and the WPI samples had the least lipid oxidation. TPC, mold, and yeast at the end of storage were the least with the WPI treatment. Both the storage period and coating material choice significantly influenced the sensory scores that declined throughout the storage. Overall, the WPI coating treatment gave the best results.
\end{abstract}


Keywords: duck egg; salting; coating; storage; temperature; quality.

\section{INTRODUCTION}

Hen and duck eggs are common, inexpensive and versatile and contribute nutrition to the human diet. They have been used as a key ingredient all over the world in breakfasts, household meals, baking and in various food products. Eggs are a good source of high-quality protein and provide significant levels of several vitamins and minerals. The salted duck egg is a traditional and popular egg product in Thailand. Normally these are made either by brining eggs in saline solution or by coating eggs with soil paste mixed with salt for about 7-30 days [1]. In southern Thailand, especially in Chaiya district of Surat Thani province, duck eggs are predominantly treated with salt-infused mud coating. Regarding quality of salted duck eggs, the desirable characteristics of salted egg yolk include orange-red color, oil exudation, and grittiness. Moreover, saltiness and other sensory characteristics play important roles in consumer perceptions. The microbial quality of salted duck eggs is also considered as an important quality factor influencing their shelf life [2].

Salted duck eggs are among the famous Thai delicacies, and are consumed at various stages with alternative preferences. Normally, at 3-7 days after curing they are used to make a fried salted egg, at 10-15 days after curing they are hardboiled, and at 15-20 days after curing the salted egg yolk will be separated for dessert filling and the egg white is often discarded as it is extremely salty. Generally, after the curing duck eggs, they can be washed and kept for 2-3 weeks, while the boiled salted duck eggs can be kept for up to 30 days in a refrigerator. However, when stored at room temperature, the shelf life of salted duck eggs is greatly reduced to 5-9 days due to rapidly spoilage by chemical and microbial deterioration. Several studies have tested various coating materials or surface treatments, such as antimicrobial solution [3,4], oil and wax [5], chitosan [6], whey protein isolate [7], and soy protein isolates [5] on fresh or uncured boiled eggs. However, to the best of our knowledge, to date, no such studies are available on hardboiled salted duck eggs. The present study was aimed to investigate four alternative surface coatings, namely paraffin wax, chitosan, whey protein isolates, and soy protein isolates, at fixed concentrations, to explore their effects on physicochemical properties, consumer perception, and shelf life of hardboiled Chaiya salted duck eggs.

\section{MATERIAL AND METHODS}

\section{Raw Materials}

Salted duck (Anas platyrhynchos) eggs were purchased from a local producer in Chaiya district, Surat Thani province, Thailand. The collected samples had been cured in salted mud coating for 15 days and weighed approximately $65-75 \mathrm{~g}$ per egg. All the eggs were thoroughly washed to remove mud or dirt on them, and then they were hardboiled in boiling water for $20 \mathrm{~min}$ and followed by immediate cooling in cold water $\left(2 \pm 1^{\circ} \mathrm{C}\right)$ to stopped further cooking (Figure 1). After that, the eggs were carefully collected in order not to crack the surface, and they were dried in the blow of an electric fan for $4 \mathrm{~h}$, followed by coating with the alternative materials. Eggs without coating were labeled 'uncoated' and were used as the control group. The coating materials such as paraffin wax (PW), chitosan $(\mathrm{CH})$, whey protein isolates (WPI), and soy protein isolates (SPI), were obtained from the commercial suppliers in Thailand. Except for the PW coating, all the coating materials used in this study were of food grade. 


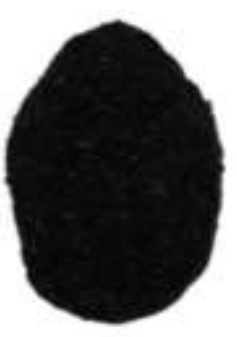

A

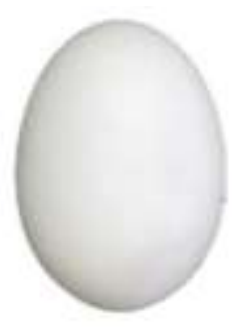

B

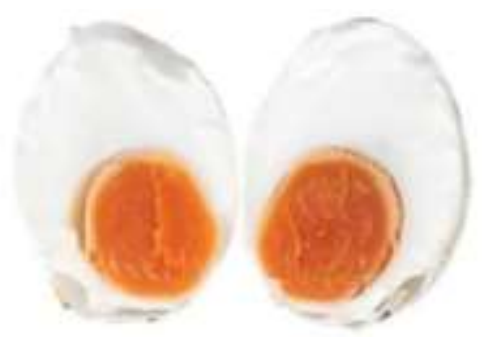

C

Figure 1. Salt coated duck egg (A), hardboiled salted duck egg (B) and sliced hardboiled salted duck egg $(\mathbf{C})$

\section{Preparation and Application of Coating Materials}

For PW coating, PW was prepared using the method proposed in Biladeau and Keener [5]. Prior to coating, PW was fully melted at $60^{\circ} \mathrm{C}$ and then applied to coat the eggs. For $\mathrm{CH}$ coating, the $\mathrm{CH}$ coating solution was prepared by the method of Bhale et al. [6] $\mathrm{CH}(1 \%)$ was dissolved in acetic acid solution (2\%), and after $\mathrm{CH}$ was completely dissolved, the $\mathrm{pH}$ of the solution set to 5.6 by $1 \mathrm{~N} \mathrm{NaOH}$ and then used for coating the eggs. For WPI coating, the WPI coating solution was prepared using the method of Caner [7]. WPI (18\%) was thoroughly dissolved in distilled water and glycerol was then added in the ratio of 2.5:1 (WPI: glycerol). After that, the mixture was set to $\mathrm{pH} 7$ and was then kept at $80{ }^{\circ} \mathrm{C}$ with continuous stirring until complete dissolution. Then, the coating solution was cooled to room temperature and used for coating. For SPI coating, SPI coating solution was prepared in accordance with Wong, Herald [8]. $5 \mathrm{~g}$ of SPI was mixed with $3 \mathrm{~g}$ of glycerol and dissolved in $92 \mathrm{ml}$ of distilled water; then the coating mixture was set to $\mathrm{pH} 10.5$ using $\mathrm{NaOH}(1 \mathrm{~N})$ and heated to $77^{\circ} \mathrm{C}$ for complete dissolution. After the SPI coating solution was cooled down to room temperature, it was used for coating.

All these coatings were applied by immersion: the eggs were manually immersed in the coating solution for $1 \mathrm{~min}$, except for with the PW coating that had 5 seconds immersion due to quick hardening. After immersion, the eggs were carefully racked to dry the surfaces completely. Prior to shelf life studies, the coated eggs were assessed for any coating defects and/or cracks, and defective cases were discarded. After drying, the eggs were stacked on plastic trays and were kept under ambient conditions $\left(30 \pm 2{ }^{\circ} \mathrm{C}\right)$ for up to 15 days. Every 5 days, the samples ( 25 eggs per treatment and per interval) were collected for the following quality measurements.

\section{Quality Measurements}

\section{Physicochemical Analysis}

The egg samples were sliced vertically into half and then were measured for the color coordinates such as lightness $\left(\mathrm{L}^{*}\right), \mathrm{a}^{*}$, and $b^{*}$ of both egg white and egg yolk, using $a$ colorimeter. The values were further converted to chroma $\left(C^{*}\right)$ and hue $\left(h^{\circ}\right)$. Shell strength was measured in accordance with the method of Wong, Herald [8]. The results are expressed as $\mathrm{kg}$ force. Weight loss of the samples was measured in accordance with the method of Wong, Herald [8]. The results are expressed as percentages. For the chemical quality analysis, the eggs were peeled and made into a smooth paste and then measured. The water activity $\left(a_{w}\right)$ of a sample was measured using the Dew point water activity meter (Aqua Lab 4TE, USA). The moisture contents were measured with an infrared moisture analyzer (MA 160, Sartorius, Germany), and results are expressed as percentages by mass. $\mathrm{pH}$ was measured using a digital $\mathrm{pH}$ meter (Mettler-Toledo, Germany). Salt content in the samples was analyzed in accordance with the method of Tan, Phatthanawiboon [9], and results are expressed as $\% \mathrm{NaCl}$ by mass. Thiobarbituric acid reactive substances (TBARS) was assayed by following the method of Cherian, Traber [10], and results are expressed as mg malonaldehyde/kg sample. 


\section{Microbiological Analysis}

The coated egg samples were washed with sterile distilled water (or scraped with a sterile knife and then washed with sterile distilled water, in the case of PW samples) and then in an aseptic condition, it was sliced vertically into halves. Egg white and egg yolk were sampled for microbiological analysis. The total plate count and yeast and mold counts were done according to BAM [11] and results are expressed as log CFU/g.

\section{Sensory Evaluation}

\section{Descriptive Profiling}

Quantitative Descriptive Analysis (QDA) was carried out [12]. Samples were evaluated by trained panelists at the university. The quality standard of a salted duck egg issued by Thailand Community Product Standard (TCPS) [2] as presented in Table 1 was used as the guidelines for sensory attribute descriptors. For each attribute, the panelists created a 15-centimeter unstructured line scale with descriptor labels at either end. The fresh boiled salted duck egg was chosen as a reference sample, in order to achieve reduced variation in panelist responses. The panel defined the intensity of the reference sample for every sensory attribute, and in the second phase all coated salted duck eggs were evaluated in comparison to the control. Assessors rated the samples individually according to the questionnaires, using a balanced test design, in which serving order was randomized for each assessor. The responses were converted to numeric values ranging from 0 to 15 . The sensory attributes were subjected to statistical evaluation.

Table 1. Attributes and descriptive terms of profile analysis of salted egg white and salted egg yolk.

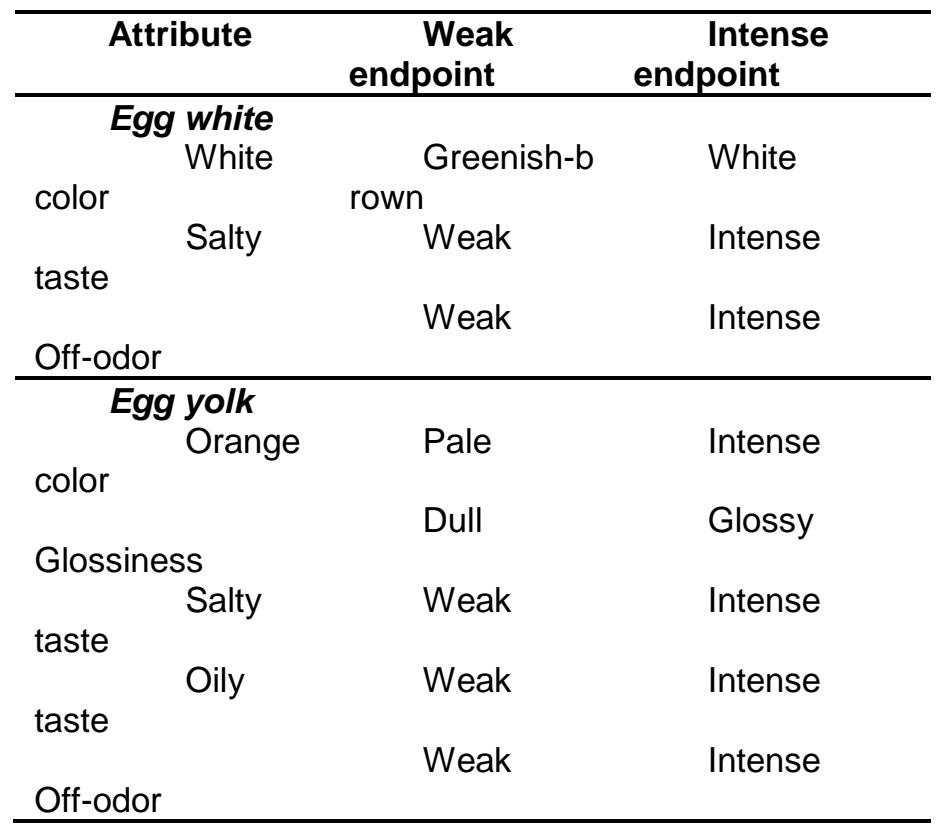

Acceptance Tests

Acceptance tests [12] were conducted with 30 consumers (recruited at the university; 18 females/12 males; 18-52 years of age) to determine overall acceptance. A 9-point Hedonic scale ( 1 = dislike extremely, $5=$ neither like nor dislike, $9=$ like extremely) was used.

\section{Statistical Analysis}

All experiments in this study were done in three replications, and the data are shown as mean \pm standard deviation. The statistical significance of differences was analyzed by 
one-way analysis of variance (ANOVA) in SPSS v6 for Windows. Duncan's New Multiple Range Test (DMRT) was used for differences between means.

\section{RESULTS AND DISCUSSION}

\section{Physical Qualities}

Color coordinates of coated and uncoated egg white and egg yolk during storage are shown in Figures $2 \mathrm{~A}-2 \mathrm{~F}$. The significant changes in color were observed during the storage. The difference in color changes between the egg white and egg yolk was not much in comparison with $L^{*}$ and $h^{\circ}$ values. $C^{*}$ declined in egg white, while in egg yolk the $C^{*}$ tended to increase gradually throughout the storage. The coating treatments of eggs reasonably controlled color changes relative to the uncoated samples. There were no differences between the actual alternative coatings in the colors of egg white or egg yolk. Generally, extended brining significantly affects the color of hardboiled duck eggs, and the egg yolk is more affected than the egg white. Kaewmanee, Benjakul [13] reported that hardboiled salted duck egg color changes are mainly influenced by their moisture, salt, and free lipid contents. The carotenoids and riboflavin are solubilized with the free fatty acids and gradually get thickened, due to continuous moisture loss in the egg yolks [14]. This is concordant with the present study, and as the pigments get concentrated the $C^{*}$ increased. Caner [7] reported that an edible coating could keep the egg color better, as it controlled the moisture loss to be lesser than for uncoated eggs. On the other hand, Kim, Daeschel [15] mentioned that there were no differences in color profile between coated and uncoated eggs during prolonged storage. This suggests that the effects of coating on quality loss could depend on samples and experimental conditions.

Shell strengths of the coated and uncoated hardboiled eggs are presented in Figure 3A. The results show that during storage the shell strength steadily decreased. The coated eggs had significantly better shell strengths than the uncoated ones. However, alternative coatings did not differ much. The WPI and PW coated eggs had the highest strengths at the end of the storage. Eggshells hermetically protect eggs against spoilage or invasion by pathogenic bacteria, but the shells may be damaged during handling, transport, and storage. Normally, the eggshell strength is the combination of material strength and structural strength. During prolonged curing and boiling could weaken the strength of the eggshell. The basic role of the coatings is to strengthen the eggshells by filling their pores $[16,17]$. Furthermore, the prolonged storage could possibly weaken the structural strength of eggshell by generating a reaction between sodium chloride and calcium carbonate. Damron [18] also observed a decreased eggshell strength after the prolonged accumulation of sodium chloride. The weight losses of coated and uncoated hardboiled salted duck eggs are shown in Figure 3B. Caner [7] reported that the weight loss of eggs during storage is among important quality criteria. Prolonged storage significantly affected the weights of salted duck eggs, with or without coating. The uncoated eggs expectedly had more weight loss than with coating. Among the coatings, WPI gave the highest weight loss, while the least weight loss was observed with PW coating. During boiling, water gets trapped by denatured proteins in a gel. Prolonged storage at ambient temperature could degrade that gel and release trapped water, enabling moisture loss. Rahault-Godbert et al. [19] found that protein stability and antimicrobial stability have significantly influenced by storage temperature and time. 

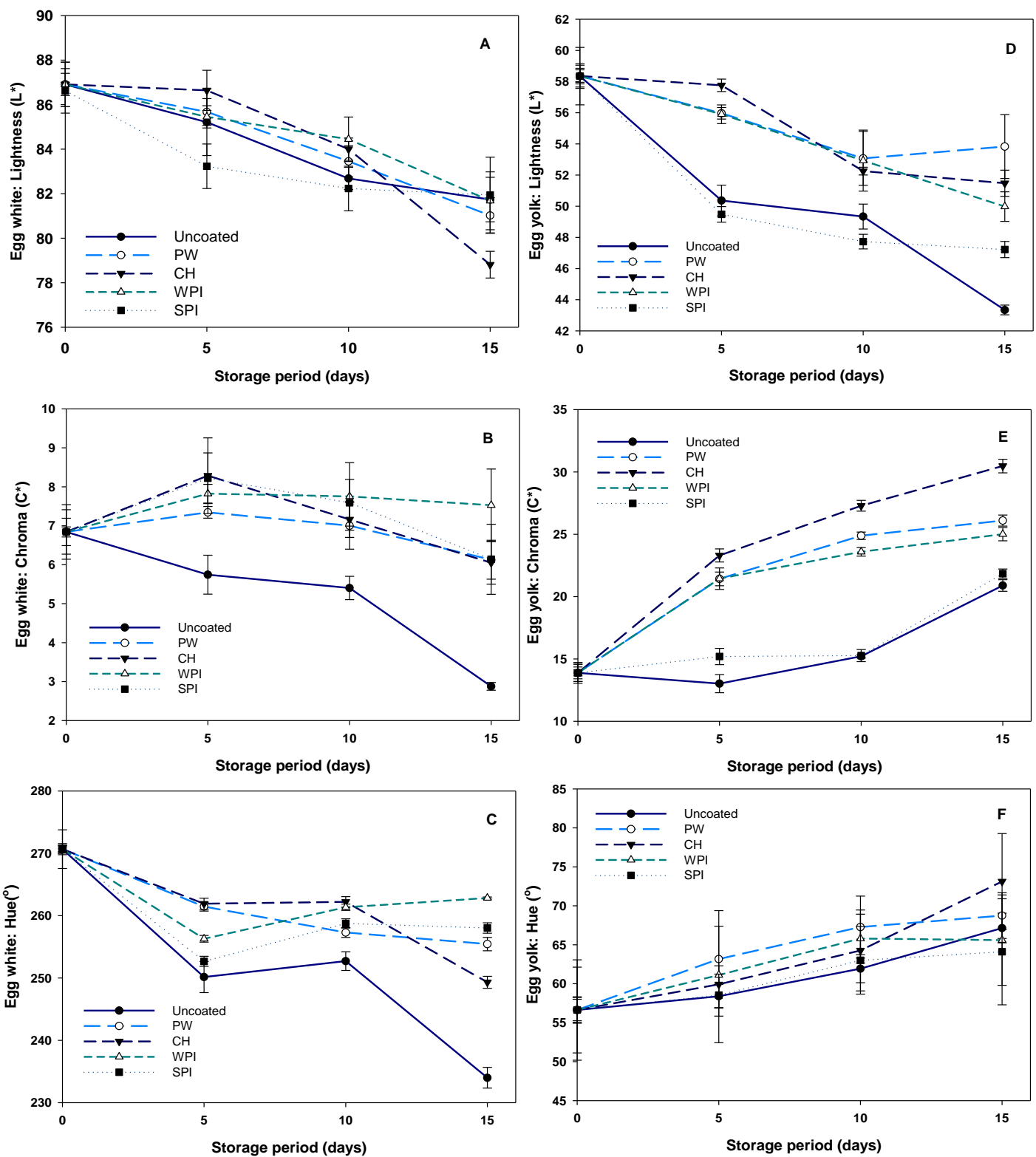

Figure 2. Time profiles of lightness $\left(L^{*}\right)$, chroma $\left(C^{*}\right)$, and hue $\left(h^{\circ}\right)$ of salted duck eggs with alternative coatings during storage under ambient temperature
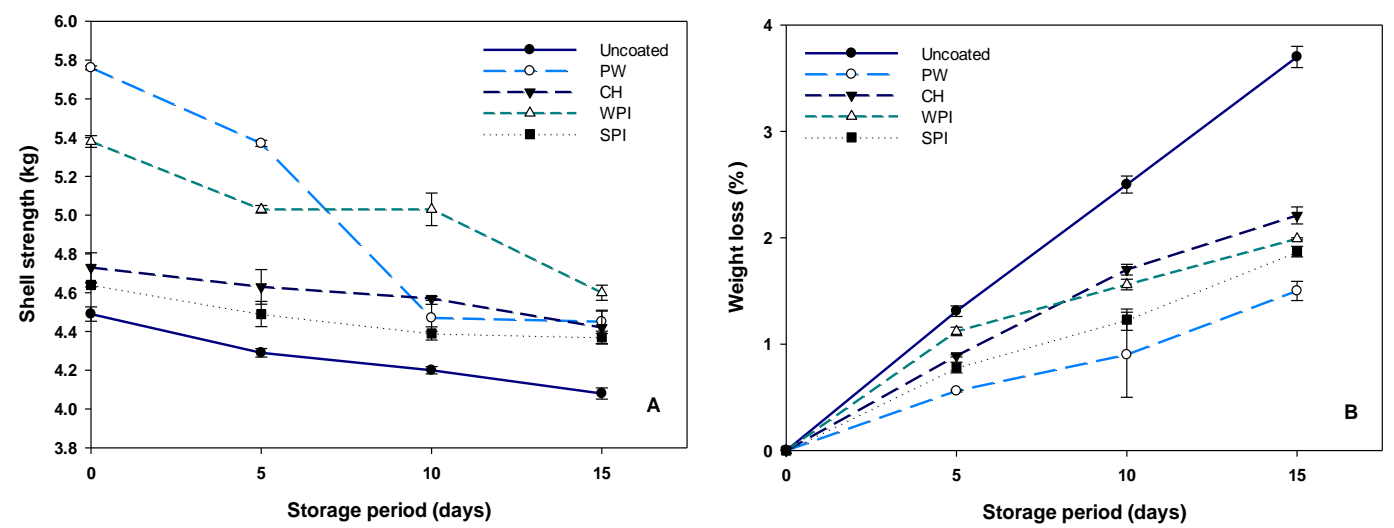

Figure 3. Observed shell strength and weight loss of salted duck eggs with alternative coatings during storage under ambient temperature 


\section{Chemical Qualities}

The chemical qualities such as $a_{w}$, moisture content, $\mathrm{pH}$, salt content and TBARS of coated and uncoated hardboiled eggs are presented in Table 2. The $a_{w}$ was stable throughout the storage period. On the other hand, moisture content decreased gradually throughout the storage. However, the changes in water activity and moisture content did not significantly differ. In addition, the changes in moisture content are concordant with the weight loss results (see Figure 3B). PW coated samples retained more moisture than the others, indicating that the PW coating could provide a tight seal on the eggshell, reducing evaporation and moisture loss. Shittu and Ogunjinmi [20] observed reduced moisture losses for PW coated raw and cooked eggs during prolonged storage. The $\mathrm{pH}$ of coated and uncoated samples slightly increased during prolonged storage $(P \geq 0.05)$. Previous studies have observed a similar trend in $\mathrm{pH}$ of raw and hardboiled eggs during storage [15,21]. Generally, $\mathrm{CO}_{2}$ plays a key role in increase and/or decrease of $\mathrm{pH}$ in eggs, as it adversely affects the egg albumin during storage. In the present study, the $\mathrm{pH}$ levels did not differ between the alternative coatings $(P \geq 0.05)$, indicating that the coatings provided effective $\mathrm{CO}_{2}$ barriers. The salt contents of coated and uncoated hardboiled eggs are shown in Table 2. Salt fraction increased in the samples during storage and was significantly influenced by coating. Among the samples, the uncoated and $\mathrm{CH}$ samples showed high salt contents (> $2 \%)$, while the other treatments retained salt at a lower level $(<2 \%)$. Kaewmanee, Benjakul [22] reported that dehydration of egg white and egg yolk could increase the salt content. This is in accordance with the present study. TBARS steadily increased, indicating gradual lipid peroxidation as storage progressed (Table 2). Among the samples, WPI and PW treatments exhibited good control of TBARS, while SPI coating failed to protect against it. The results show that prolonged storage gradually weakened the coating and TBARS progressed in the samples. Normally, the egg yolk is the predominant contributor of MDA through lipid peroxidation, as it has abundant lipids. On the other hand, the accumulation of lipid peroxide did not significantly differ between treatments. In addition, the TBARS in the yolks of hardboiled eggs did not increase rapidly, because this part is sealed and protected within aggregated protein egg white and protein hydrolysate. Hayat, Cherian [23] reported that a controlled of TBARS was due to the malondialdehyde reacted with TBA to reduce the TBARS production and/or MDA convert to dimers or trimers and become unavailable to TBARS.

\section{Microbiological Qualities}

The microbial quality of coated and uncoated hardboiled eggs during ambient temperature storage is shown in Figures 4A-4B. During storage, microbial growth progressed in all the samples. The uncoated eggs exhibited more bacterial, yeast and mold growth than the coated cases. Among the coatings, WPI treatment gave the least surface microbial growth, followed by $\mathrm{CH}, \mathrm{SPI}$, and PW. The results indicate that bacterial growth dominated over yeast and mold growth. The PW coated eggs had more microbial growth than with the other coatings, due to the dehydration moisture from the egg getting trapped between the coating and the egg surface. Normally, the antimicrobial effects of coatings vary by application concentration and the coating method. TCPS [2] reported that less than $1 \times$ $10^{6} \mathrm{CFU} / \mathrm{g}$ TPC microbial loads are acceptable on hardboiled salted duck eggs, while yeast and mold should be below $100 \mathrm{CFU} / \mathrm{g}$. Brandelli, Detroit [24] reported that whey proteins exhibit strong protecting activity against several pathogenic bacteria. In addition, several studies have reported that chitosan naturally exhibited antimicrobial activity, and it mainly depended on the molecular weight, the degree of deacetylation, solubility, $\mathrm{pH}$, positive charge, hydrophilic and hydrophobic interactions [25,26]. Furthermore, the flux of moisture out through the egg shell and coating may also erode the coating and reduce its antimicrobial potency. 
Table 2. Changes in chemical quality of hardboiled salted duck eggs with alternative coatings during storage under ambient temperature

\begin{tabular}{|c|c|c|c|c|c|}
\hline \multirow{2}{*}{ Parameter } & \multirow{2}{*}{ Treatment } & \multicolumn{4}{|c|}{ Storage time (days) } \\
\hline & & 0 & 5 & 10 & 15 \\
\hline \multirow[t]{5}{*}{$a_{w}$} & Uncoated & $0.96 \pm 0.01^{\mathrm{NS}}$ & $0.96 \pm 0.00^{\mathrm{NS}}$ & $0.95 \pm 0.00^{\mathrm{NS}}$ & $0.96 \pm 0.00^{\mathrm{NS}}$ \\
\hline & PW & $0.97 \pm 0.01^{\mathrm{NS}}$ & $0.97 \pm 0.00^{\mathrm{NS}}$ & $0.97 \pm 0.00^{\mathrm{NS}}$ & $0.97 \pm 0.00^{\mathrm{NS}}$ \\
\hline & $\mathrm{CH}$ & $0.97 \pm 0.00^{\mathrm{NS}}$ & $0.97 \pm 0.00^{\mathrm{NS}}$ & $0.97 \pm 0.00^{\mathrm{NS}}$ & $0.97 \pm 0.01^{\mathrm{NS}}$ \\
\hline & WPI & $0.95 \pm 0.00^{\mathrm{NS}}$ & $0.96 \pm 0.01^{\mathrm{NS}}$ & $0.96 \pm 0.02^{\mathrm{NS}}$ & $0.96 \pm 0.00^{\mathrm{NS}}$ \\
\hline & SPI & $0.97 \pm 0.00^{\mathrm{NS}}$ & $0.97 \pm 0.00^{\mathrm{NS}}$ & $0.97 \pm 0.01^{\mathrm{NS}}$ & $0.97 \pm 0.00^{\mathrm{NS}}$ \\
\hline Moisture & Uncoated & $68.11 \pm 0.94^{\mathrm{aA}}$ & $66.62 \pm 1.05^{\mathrm{aA}}$ & $61.17 \pm 0.69^{\mathrm{bB}}$ & $57.19 \pm 0.33^{\mathrm{cC}}$ \\
\hline \multirow[t]{4}{*}{ content (\%) } & PW & $68.55 \pm 0.46^{\mathrm{aA}}$ & $67.44 \pm 0.17^{\mathrm{aA}}$ & $65.29 \pm 0.41^{\mathrm{bA}}$ & $64.09 \pm 0.63^{\mathrm{bA}}$ \\
\hline & $\mathrm{CH}$ & $68.78 \pm 0.81^{\mathrm{aA}}$ & $66.56 \pm 0.59^{\mathrm{abA}}$ & $64.49 \pm 0.68^{\mathrm{bA}}$ & $59.63 \pm 1.16^{\mathrm{CB}}$ \\
\hline & WPI & $68.73 \pm 0.65^{\mathrm{aA}}$ & $67.99 \pm 0.12^{\mathrm{aA}}$ & $65.69 \pm 0.52^{\mathrm{bA}}$ & $64.96 \pm 0.33^{\mathrm{bA}}$ \\
\hline & SPI & $68.57 \pm 0.20^{\mathrm{aA}}$ & $67.27 \pm 0.48^{\mathrm{aA}}$ & $61.41 \pm 1.09^{\mathrm{bB}}$ & $58.10 \pm 0.46^{\mathrm{cB}}$ \\
\hline \multirow[t]{5}{*}{ pH } & Uncoated & $7.22 \pm 0.08^{\mathrm{aA}}$ & $7.16 \pm 0.00^{\mathrm{aA}}$ & $7.09 \pm 0.06^{\mathrm{bB}}$ & $6.93 \pm 0.01^{\mathrm{bB}}$ \\
\hline & PW & $7.17 \pm 0.00^{\mathrm{aAB}}$ & $7.16 \pm 0.01^{\mathrm{aA}}$ & $7.06 \pm 0.12^{\mathrm{bA}}$ & $7.05 \pm 0.16^{\mathrm{bB}}$ \\
\hline & $\mathrm{CH}$ & $7.28 \pm 0.03^{\mathrm{aA}}$ & $7.11 \pm 0.05^{\mathrm{bAB}}$ & $7.01 \pm 0.05^{\mathrm{cB}}$ & $6.93 \pm 0.05^{\mathrm{cB}}$ \\
\hline & WPI & $7.09 \pm 0.02^{\mathrm{aB}}$ & $7.07 \pm 0.03^{a B}$ & $7.04 \pm 0.05^{\mathrm{aB}}$ & $6.96 \pm 0.10^{\mathrm{bB}}$ \\
\hline & SPI & $7.29 \pm 0.04^{\mathrm{aA}}$ & $7.24 \pm 0.15^{\mathrm{aA}}$ & $7.19 \pm 0.01^{\mathrm{bA}}$ & $7.19 \pm 0.06^{\mathrm{bA}}$ \\
\hline Salt & Uncoated & $1.55 \pm 0.06^{\mathrm{bA}}$ & $1.59 \pm 0.00^{\mathrm{bB}}$ & $2.01 \pm 0.02^{\mathrm{aAB}}$ & $2.04 \pm 0.03^{\mathrm{aC}}$ \\
\hline \multirow[t]{4}{*}{ content (\%) } & PW & $1.44 \pm 0.09^{\mathrm{bAB}}$ & $1.58 \pm 0.19^{\mathrm{bB}}$ & $2.07 \pm 0.10^{\mathrm{aA}}$ & $2.19 \pm 0.04^{\mathrm{aB}}$ \\
\hline & $\mathrm{CH}$ & $1.46 \pm 0.13^{\mathrm{cAB}}$ & $1.82 \pm 0.04^{\mathrm{bA}}$ & $1.87 \pm 0.11^{\mathrm{bBC}}$ & $2.32 \pm 0.03^{\mathrm{aA}}$ \\
\hline & WPI & $1.41 \pm 0.04^{\mathrm{bAB}}$ & $1.52 \pm 0.06^{\mathrm{bB}}$ & $1.50 \pm 0.11^{\mathrm{bD}}$ & $1.95 \pm 0.03^{\mathrm{aCD}}$ \\
\hline & SPI & $1.34 \pm 0.03^{\mathrm{bB}}$ & $1.45 \pm 0.00^{\mathrm{bB}}$ & $1.82 \pm 0.07^{\mathrm{aC}}$ & $1.91 \pm 0.10^{\mathrm{aD}}$ \\
\hline TBARS (mg & Uncoated & $0.12 \pm 0.02^{\mathrm{cBC}}$ & $0.17 \pm 0.02^{\mathrm{bA}}$ & $0.18 \pm 0.00^{\mathrm{bA}}$ & $0.29 \pm 0.00^{\mathrm{aAB}}$ \\
\hline malonaldeh & PW & $0.16 \pm 0.02^{\mathrm{bA}}$ & $0.16 \pm 0.02^{\mathrm{bA}}$ & $0.16 \pm 0.03^{\mathrm{bAB}}$ & $0.21 \pm 0.01 \mathrm{aCD}$ \\
\hline yde/kg & $\mathrm{CH}$ & $0.14 \pm 0.01^{\mathrm{bAB}}$ & $0.18 \pm 0.02^{\mathrm{bA}}$ & $0.18 \pm 0.02^{\mathrm{bA}}$ & $0.25 \pm 0.04^{\mathrm{aBC}}$ \\
\hline \multirow[t]{2}{*}{ sample) } & WPI & $0.11 \pm 0.01^{\mathrm{cC}}$ & $0.12 \pm 0.01^{\mathrm{cB}}$ & $0.14 \pm 0.01^{\mathrm{bB}}$ & $0.17 \pm 0.02^{\mathrm{aD}}$ \\
\hline & SPI & $0.16 \pm 0.02^{\mathrm{bA}}$ & $0.16 \pm 0.01^{\mathrm{bA}}$ & $0.18 \pm 0.02^{\mathrm{bA}}$ & $0.33 \pm 0.05^{\mathrm{aA}}$ \\
\hline
\end{tabular}

Note. Different lowercase superscripts indicate significant differences within a row, and different uppercase superscripts indicate significant differences within a column. NS indicates non-significant differences
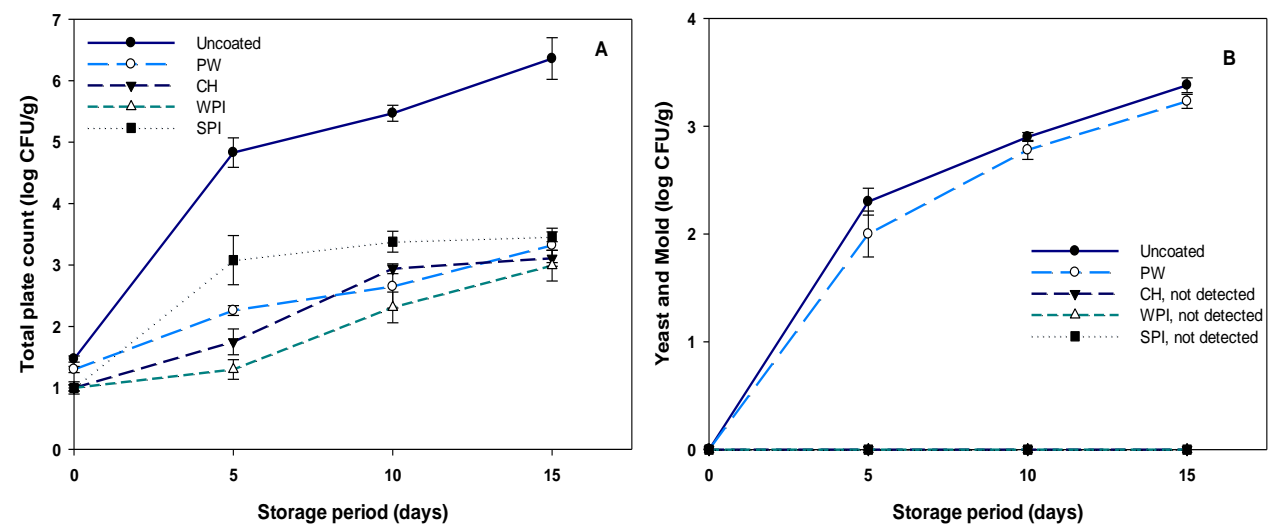

Figure 4. Microbial activity of salted duck eggs with alternative coatings during storage under ambient temperature. ND indicates non-detection. 


\section{Sensory Investigation}

The sensory investigation of egg white and egg yolk with the various coating treatments during ambient temperature storage are shown in Figures 5-7. All the sensory tests were conducted after confirming from the microbial study that the samples are safe for consumption. The sensory scores of egg white steadily decreased during storage, indicating that the panelist did not like the quality of color, salty taste or off-odor during prolonged storage. With WPI coating the egg white samples obtained slightly higher scores for color and lower scores for off-odor than with the other treatments (Figures 5). On the other hand, the salty taste scores did not significantly differ by treatment. In addition, egg yolk is highly demanded as a product unique to salted duck eggs. The egg yolk sensory qualities were not significantly influenced by the type of coating or storage time (Figures 6). The egg yolk sensory characteristics such as orange color, gloss, salty taste, oily taste, and off-odor gradually declined during prolonged storage. The orange color, gloss, and oily taste scores were found to decrease with all treatments, whereas salty taste and off-odor gradually increased. The different coating treatments were not significantly differed among each other and however, it significantly differed when compared with the control samples. Overall the acceptance scores were highest with WPI followed by SPI, CH, PW, and uncoated samples (Figure 7).
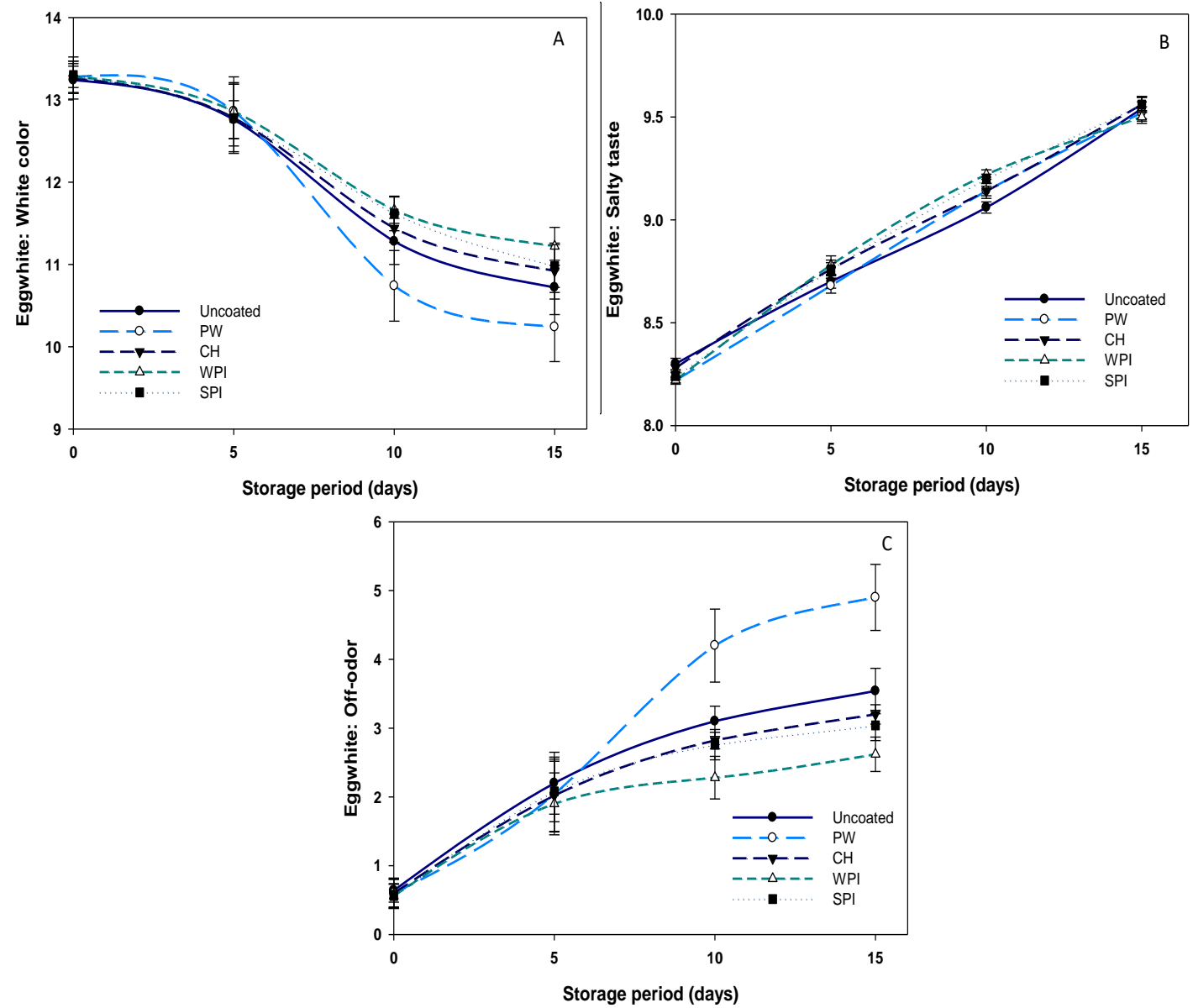

Figure 5. Time profiles of the sensorial characteristics (white color, salty taste and off odor) of salted duck egg white with alternative coatings during storage under ambient temperature 

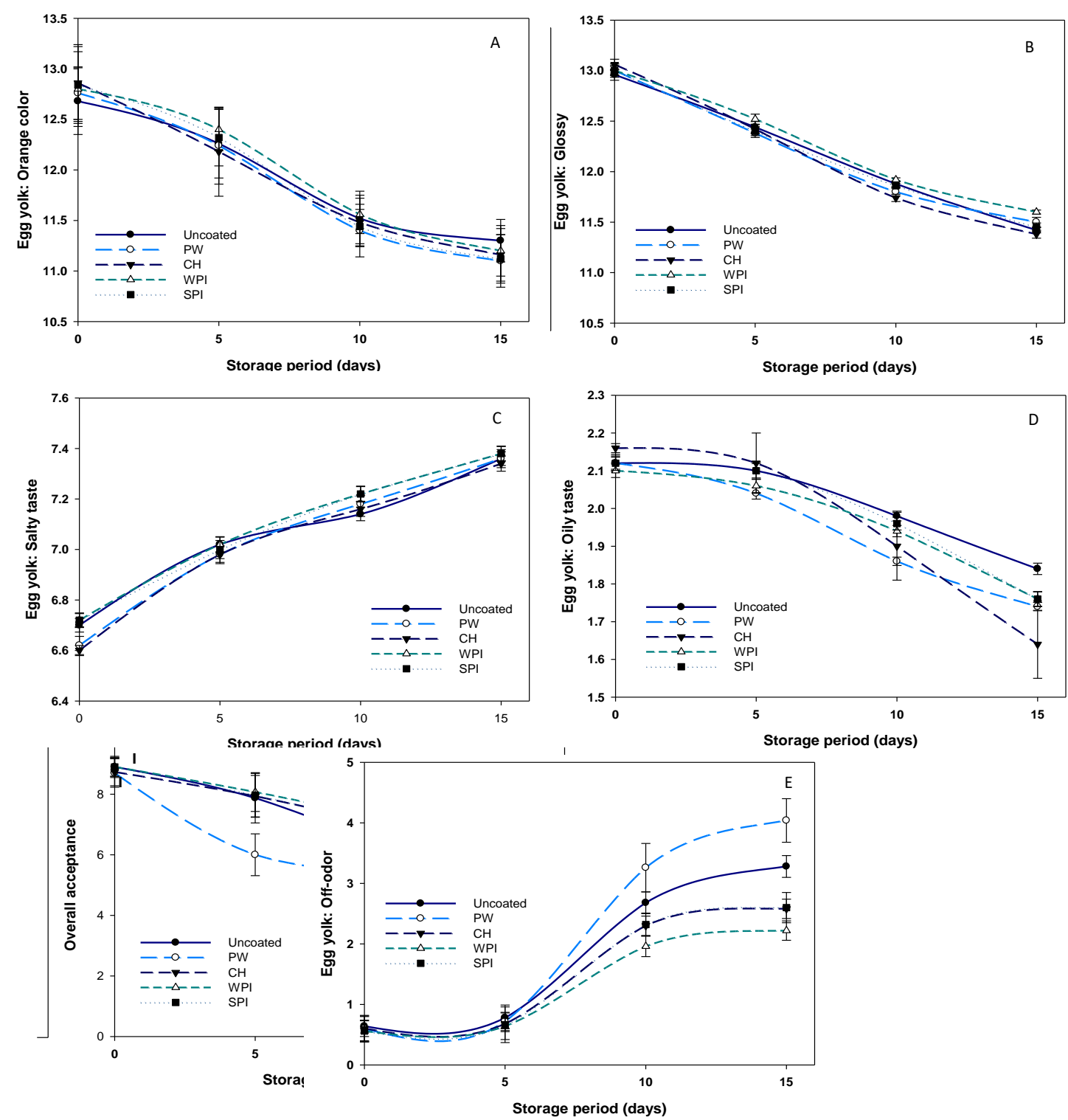

Figure 6. Time profiles of the sensorial characteristics (orange color, glossy, silky taste, oily taste and off-odor) of salted duck egg yolk with alternative coatings during storage under ambient temperature

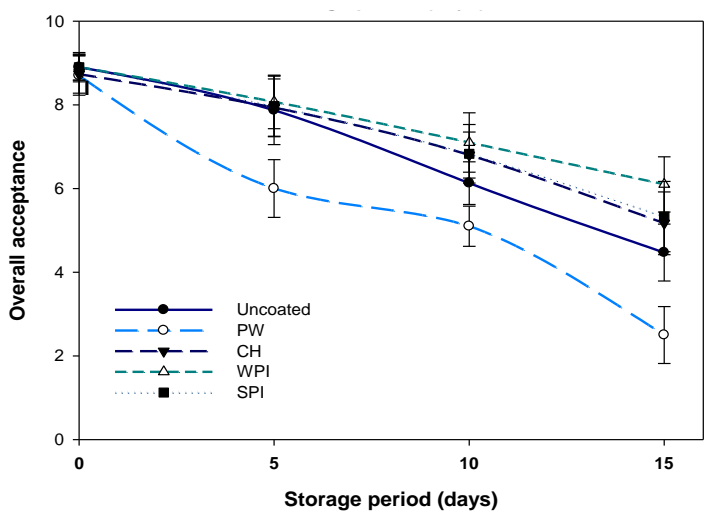

Figure 7. Time profiles of the sensorial characteristics (Overall acceptance) of salted duck egg with alternative coatings during storage under ambient temperature 


\section{CONCLUSION}

The present study tested the effects of edible and non-edible coatings on the quality changes of hardboiled salted duck eggs during room temperature storage. Prolonged storage significantly affected the quality characteristics of hardboiled salted duck eggs. The uncoated egg samples suffered from more severe quality deterioration than the coated eggs. On the other hand, some coatings also failed to protect the eggs against quality loss. PW coating controlled the physical loss of quality, whereas WPI coating had effectively controlled the chemical and microbial deterioration. WPI coating gave the overall highest acceptance scores in sensory tests. The results indicate that WPI could be a suitable coating material for extending the shelf life at ambient temperature. The present study recommends that using vacuum packaging along with WPI coating could extend the shelf life further past about three weeks; this remains a potential topic of further studies.

Funding: This research was funded by the Food Innovation and Research Institute, Prince of Songkla University, Grant FIRIn 2557/003. We would also like to thank for the additional financial support given by the Prince of Songkla University, Surat Thani Campus, in 2016.

Acknowledgment: The Food Innovation and Product Development (FIPD) Laboratory is acknowledged for providing laboratory space and equipment support.

Conflicts of Interest: The authors declare no conflict of interest.

\section{REFERENCES}

1. Ganesan $\mathrm{P}$, Kaewmanee T, Benjakul S, Baharin BS. Comparative study on the nutritional value of pidan and salted duck egg. Korean J Food Sci Anim Resour. 2014;34(1):1-6.

2. (TCPS) Thailand Community Product Standard. Whole Salted Eggs. Bangkok (Thailand): Community Product Standards Division, Thai Industrial Standards Institute; 2007. p. 7.

3. Harlina PW, Hu MM, Legowo A, Pramono Y. The effect of supplementation garlic oil as an antibacterial activity and salting time on the characteristics of salted egg. J Appl Food Tech. 2012;1(4):121-8.

4. Kaewmanee T, Benjakul S, Visessanguan W. Effect of acetic acid and commercial protease pretreatment on salting and characteristics of salted duck egg. Food Bioprocess Tech. 2012;5(5):1502-10.

5. Biladeau $A$, Keener $K$. The effects of edible coatings on chicken egg quality under refrigerated storage. Poult Sci. 2009;88(6):1266-74.

6. Bhale S, No H, Prinyawiwatkul W, Farr A, Nadarajah K, Meyers S. Chitosan coating improves shelf life of eggs. J Food Sci. 2003;68(7):2378-83.

7. Caner C. Whey protein isolate coating and concentration effects on egg shelf life. J Sci Food Agric. 2005;85(13):2143-8.

8. Wong $\mathrm{Y}$, Herald $\mathrm{T}$, Hachmeister K. Evaluation of mechanical and barrier properties of protein coatings on shell eggs. Poult Sci. 1996;75(3):417-22.

9. Tan TC, Phatthanawiboon T, Mat EA. Quality, textural, and sensory properties of yellow alkaline noodles formulated with salted duck egg white. J Food Qual. 2016;39(4):342-50.

10. Cherian G, Traber M, Goeger M, Leonard S. Conjugated linoleic acid and fish oil in laying hen diets: effects on egg fatty acids, thiobarbituric acid reactive substances, and tocopherols during storage. Poult Sci. 2007;86(5):953-8.

11. BAM: Aerobic Plate Count. U.S.Food and Drug Administration [Internet]. [place unknown: publisher unknown]; 2001 [cited 2017 Oct 12] Available from: http://www.fda.gov/Food/FoodScienceResearch/LaboratoryMethods/ucm063346.html.

12. Meilgaard M, Civille G, Carr B. Introduction to Sensory Techniques. Florida (USA): CRC Press: Boca Raton; 2007; p. $1-5$.

13. Kaewmanee T, Benjakul S, Visessanguan W. Effects of salting processes and time on the chemical composition, textural properties, and microstructure of cooked duck egg. J Food Sci. 2011;76(2):139-74.

14. Sugino $H$, Ishikawa M, Nitoda $T$, Koketsu M, Juneja LR, Kim M, Yamamoto T. Antioxidative activity of egg yolk phospholipids. J Agric Food Chem. 1997;45(3):551-4. 
15. Kim K, Daeschel M, Zhao Y. Edible coatings for enhancing microbial safety and extending shelf life of hard-boiled eggs. J Food Sci. 2008;73(5):227-35.

16. Farag R, Daw Z, Afify A, Shallan M, Mahmoud EA. Biochemical and microbial studies on the efficiency of some coating materials for egg preservation. Int $\mathrm{J}$ Food Sci Nutr. 1994;45(4):263-73.

17. Meyer R, Spencer JV. The effect of various coatings on shell strength and egg quality. Poult Sci. 1973;52(2):703-11.

18. Damron B. Sodium chloride concentration in drinking water and eggshell quality. Poult Sci. 1998;77(10):1488-91.

19. Rehault-Godbert S, Baron F, Mignon-Grasteau S, Labas V, Gautier M, Hincke MT, Nys Y. Effect of temperature and time of storage on protein stability and anti-salmonella activity of egg white. $J$ Food Protect. 2010;73(9):1604-12.

20. Shittu TA, Ogunjinmi O. Effect of low cost shell coatings and storage conditions on the raw and cooked qualities of shell egg. CyTA-J Food. 2011;9(1):1-7.

21. Eke M, Olaitan N, Ochefu J. Effect of storage conditions on the quality attributes of shell (table) eggs. Nigerian Food J. 2013;31(2):8-24.

22. Kaewmanee $T$, Benjakul $S$, Visessanguan W. Changes in chemical composition, physical properties and microstructure of duck egg as influenced by salting. Food Chem. 2009;112(3):560-9.

23. Hayat Z, Cherian G, Pasha T, Khattak F, Jabbar M. Oxidative stability and lipid components of eggs from flax-fed hens: Effect of dietary antioxidants and storage. Poult Sci. 2010;89(6):1285-92.

24. Brandelli A, Daroit DJ, Corrêa APF. Whey as a source of peptides with remarkable biological activities. Food Res Int. 2015;73:149-61.

25. Badawy ME, Rabea El. A biopolymer chitosan and its derivatives as promising antimicrobial agents against plant pathogens and their applications in crop protection. Int $\mathrm{J}$ Carbohydr Chem. 2011;460381:1-29.

26. Goy RC, Britto D, Assis OBG. A review of the antimicrobial activity of chitosan. Polymerous. 2009;19(3):241-247. 


\section{ERRATUM}

In the Article "Influences of Different Coating Materials on the Quality Changes of Hardboiled Salted Duck Eggs under Ambient Storage", DOI number: http://doi.org/10.1590/1678-4324-2019180471, published in the journal Brazilian Archives of Biology and Technology, vol. 62, page 1.

That read:

"1University (Surat Thani Campus), Faculty of Science and Industrial Technology, Department of Food Technology, Prince of Songkla Muang, Surat Thani, Thailand."

Read:

"Prince of Songkla University, Faculty of Science and Industrial Technology, Department of Food Technology, Makhamtia, Surat Thani, Thailand" 